Article

\title{
Does Sustainability Score Impact Mutual Fund Performance?
}

\author{
Pablo Durán-Santomil ${ }^{1, *}$, Luis Otero-González ${ }^{2}$, Renato Heitor Correia-Domingues ${ }^{3}$ and \\ Juan Carlos Reboredo ${ }^{4}$ \\ 1 Departamento de Organización de Empresas y Comercialización, Universidad de Santiago de Compostela, \\ 27002 Lugo, Spain \\ 2 Departamento de Economía Financiera y Contabilidad, Universidad de Santiago de Compostela, \\ 15782 Santiago de Compostela, Spain; luis.otero@usc.es \\ 3 Departamento de Economia, Finanças e Contabilidade, Instituto Politécnico de Viana do Castelo, \\ 900-347 Viana do Castelo, Portugal; renatodomingues@por.ulusiada.pt \\ 4 Departamento de Fundamentos del Análisis Económico, Universidad de Santiago de Compostela, \\ 15782 Santiago de Compostela, Spain; juancarlos.reboredo@usc.es \\ * Correspondence: pablo.duran@usc.es
}

Received: 2 April 2019; Accepted: 21 May 2019; Published: 24 May 2019

\begin{abstract}
Given that sustainable investing constitutes a major force across global financial markets, in 2016 Morningstar began reporting Morningstar Sustainability scores. We used the 2016, 2017 and 2018 scores to study the effects of socially responsible investments (SRI) on European equity fund performance. Sustainability scores impacted positively on performance, which was consistent with the idea that the mutual funds invested in companies with better scores generate better risk-adjusted and not-risk adjusted performance. We also tested the relation on mutual fund flows and risk. The sustainability score in the previous year is significant on the flows, so higher-rated funds receive a larger volume of funds. In terms of risk, the level of sustainability is negatively related to the value at risk $(\mathrm{VaR})$ of the fund, supporting that higher scored mutual funds offer better protection against extreme losses.
\end{abstract}

Keywords: mutual fund performance; mutual fund flows; Sustainability Score; ESG score; Socially Responsible Investment; SRI

\section{Introduction}

Socially responsible investment (SRI), also known as sustainable, responsible, and impact investing, is "an investment discipline that considers environmental, social and corporate governance (ESG) criteria to generate long-term competitive financial returns and positive societal impact" (US SIF. (See http://www.ussif.org. US SIF is the Forum for Sustainable and Responsible Investment)). According to the 2016 Global Sustainable Investment Review [1], in 2016 there were $\$ 22.89$ trillion assets being professionally managed under SRI strategies in the world. Authors in Reference [2] conclude that the SRI label in the mutual fund industry is valued favorably by the market, which is an important factor that drives this growth, while authors in Reference [3] argue that social preference (instead of financial performance) is the primary factor for investors choosing SRI mutual funds.

The growing interest in SRI in recent years has led to several organizations assessing mutual funds on how well the underlying companies perform on ESG issues. In 2016, Morningstar launched a Morningstar Sustainability Rating and Score. The idea of the Morningstar Sustainability Rating is classifying mutual funds with ESG factors relative to their Morningstar category peers. The advantage of this product is that it makes it possible to find sustainable funds even if they aren't labelling 
themselves specifically as funds that support an SRI approach. The use of these scores shows an important difference to previous studies, which compare SRI funds with an index, or the most advanced studies apply a so-called matching approach, i.e., they compare the performance of SRI and non-SRI investment funds with similar characteristics (fund size, fund age, expenses, et cetera.) to properly considered management and transaction costs for both SRI funds and conventional funds [4-8]

One important research question in the mutual fund industry about SRI investing is to know how SRI mutual funds perform. There are several studies that have demonstrated that companies with social responsibility policies and practices are good investments. For example, a recent paper of [9] conducted a meta-analysis of about 2200 unique primary empirical studies. They found that the majority of studies show a positive correlation between ESG factors and financial performance. But despite the investigations carried out to date, there is still a debate about whether these types of investments can create value for investors and why they put their money here. Although according to $[10,11]$ some investors in SRI funds are willing to accept lower returns for their moral stance, the performance of SRI funds and conventional funds is still an open question. Authors in Reference [12] sustain, after a review of the most recent work in major finance journals on SRI, that "the performance of SR mutual funds and indexes are not generally significantly different to conventional funds or indexes, but again these results are also highly dependent on model specification, time period, benchmark, and other characteristics of the study".

Authors such as $[4,13]$ support the idea that SRI funds outperform market indexes. But the more conventional theory is that SRI mutual funds have the same return as any other funds, and authors such as $[7,8,14-18]$ are in line with this theory. Another theory defends that choosing SRI funds is basically a "trade off" between investing in SRI and returns, so SRI investments underperform the benchmark, for example [19]. One important recent paper is [20], which provides a new perspective because they found that the difference between socially responsible (SR) and conventional mutual funds depends on the state of the market. SR mutual funds outperform conventional mutual funds during periods of market crisis, but in non-crisis periods, SR funds underperform conventional funds.

Previous research has studied the effect of sustainability on performance exclusively using a dichotomous variable to differentiate between socially responsible funds and conventional funds. However, the results could be biased because under "socially responsible", they could have funds with very different levels of sustainability. Authors in Reference [21] conclude that there is a lack of clearly defined criteria to distinguish mutual funds as "socially responsible", and this results in inconsistently applied classifications that make it difficult to measure the performance of SRIs. Traditional methodology in empirical research is benchmarking with indices or, most recently, matched pair analysis, which was initially applied by [4], and is based on comparing returns of SRI funds and conventional funds with similar characteristics in terms of volume of assets, interception dates, et cetera. For this reason, the inclusion of sustainability scores in our work allows us to evaluate whether the degree of sustainability of the portfolio in which the funds are invested has a positive relation with performance. As far as we know, only [22,23] analyzed this effect. Authors in Reference [22] conclude that funds with higher Morningstar Sustainability scores have similar alphas from those with lower sustainability scores. Authors also observe that there is little difference in the performance or sustainability scores between self-proclaimed SRI funds versus those that fall in the top 50 and top 20 percent of Morningstar's Sustainability scores. Finally, they observe that mutual funds with higher Morningstar Sustainability metrics do not appear to be more attractive to investors compared to low scoring funds. In contrast, self-proclaimed SRI funds have performed significantly better regarding fund flows. Authors in Reference [23] use corporate social responsibility (CSR) scores to study the effect on fund performance and flows, concluding that higher values display poorer performance and weaker performance-flow relation. From an investor point of view, the advantage of using sustainability scores is that they can select their SRI, taking into consideration the funds with better scores, whether or not they are self-declared as an SRI fund. 
This paper adds to the growing literature on SRI by specifically examining the effect of the degree of sustainability, measured though Morningstar Sustainability scores included in Morningstar Direct in 2016. In particular, we assess the effect of sustainability scores and the different dimensions in which the score is subdivided (environmental, social, and governance) in the performance, in addition to the downside risk and the flow of funds. Authors in References [24,25] indicate that investors might not be very concerned with mutual funds that underperform when they are less affected in case of extreme market conditions. In this sense, the difference in the performance of ratings could be obtained at the expense of higher downside risk. But, this question has not been addressed in previous research.

On the other hand, the conventional dichotomous variable has been added to the models to evaluate to what extent the results may differ. Our empirical evidence also contributes to the literature on mutual funds that discusses whether applying a particular investment screening in portfolio selection affects the mutual fund performance, see for example [16,26]. SRI portfolios are subject to both positive and negative social screens [27]. The Portfolio theory argues that narrowing the universe of assets restricts diversification opportunities and thus the risk-adjusted performance [28]; whereas [29,30] consider that restricting investment screening allows the identification of companies with higher growth potential and better management, therefore leading to a better financial performance and risk profile. Sustainable mutual funds apply a specific portfolio screening by concentrating investments in socially conscious businesses. Although there is profuse empirical literature on the impact of social responsibility of the performance, little is known about the sustainability-based screening.

The main contribution of our paper is to fill the gap in SRI investing that, with very few exceptions [22,23], employ self-declared dichotomous variables to identify socially conscious mutual funds. Differently to these two exceptions, that focus on U.S. domestic mutual funds, we extend the analysis of the degree of sustainability to the European market, which accounts for over half of global SRI assets as sustainable investing takes off [1]. Our empirical results for the years 2015 and 2016 show that a large number of funds were not declared sustainable but their portfolio is comparable to sustainable mutual funds. Furthermore, the sustainability score is significant in explaining the level of performance, downside risk, and flows. We also achieved equivalent results for the three dimensions of sustainability (environmental, social and corporate). The signs are different on performance and downside risk when the conventional dummy to declare social mutual funds is used.

The remainder of this paper is laid out as follows. In Section 2, we review the related literature on SRI performance, in Section 3 we describe our data and the performance evaluation metrics, in Section 4 we describe our empirical methods and results, in Section 5 we conduct robustness tests and, finally, we draw conclusions from our research.

\section{Literature Review}

Over the last few years, SRI investment research has been growing. The CFA Institute, which is a global association for investment professionals, states that "a key idea in the discussion of ESG issues is that systematically considering ESG issues will likely lead to more complete analyses and better-informed investment decisions" and "that every investment analyst should be able to identify and properly evaluate investment risks, and ESG issues are a part of this evaluation" [31]. For this association, there are basically two investors interested in considering ESG issues: value-motivated and values-motivated investors. We focus on the first kind of investors concerned with the financial performance of their SRI funds.

Authors in Reference [14] developed three hypotheses regarding the performance of SRI mutual funds. The first hypothesis is that SRI fund performance equals that of conventional funds, which is consistent with a market that does not regard the social responsibility feature. The second hypothesis is that SRI fund performance is lower than that of conventional funds, which is consistent with a market that values the social responsibility feature. Finally, the third hypothesis is that SRI fund performance is higher than that of conventional funds. There are several arguments which could explain why SRI mutual funds can outperform, in financial terms, the conventional funds (which do not consider ESG 
factors). First, SRI mutual funds have a higher proportion of their portfolio in the segment of small companies; these companies are better adapted to market changes $[5,13]$ and may also be more profitable in the long run. Second, social companies are more efficient, better managed and develop better in the market [14]. From a theoretical point of view social companies can reduce costs (penalties, et cetera) or increase revenues (innovative products, greater employee effort, better public perception, increasing the likelihood that consumers will purchase the company's products or its share price, attract socially conscious customers, et cetera) [32,33]. In contrast, one important argument of the detractors of SRI funds is that the universe of possible investments of these funds (individual companies) is small, so they assume a higher investment risk because of the lack of diversity. Authors in References [30,34] replicate 10,000 pairs of SRI and conventional portfolios to test the impact of SRI screening on performance, finding no significant difference in the risk-adjusted return of screened and unscreened portfolios. They conclude that a typical SRI fund will neither gain nor lose from screening its portfolio. But [35] find that negative screening implies an opportunity cost, because excluding controversial stocks for an investment portfolio may reduce financial performance. Authors such as $[36,37]$ argue that SRI mutual funds managers need more information than conventional funds about the companies in which they invest; they base their decisions on deeper, more complete, and higher quality information, resulting in a significant reduction in the risk of their investment decisions. Empirical evidence of some authors, such as $[4,13]$, supports the idea that SRI funds outperform conventional investments. But there is also evidence to support the idea that SRIs are neutral to financial performance ([7,8,14-18], among others), or that SRI funds underperform conventional investments, for example [19].

The first study about SRI investment was done by [13], where these authors found that SRI investment funds did not under or outperform the index benchmark. They used 15 British Ethical funds, finding weak evidence that 15 UK SRI funds outperformed two stock market indices. Authors in Reference [14] conducted a similar study where the difference of means of excess returns was not significant and only one of 17 mutual funds had a positive Jensen's alpha. Authors in Reference [38] improved their prior work by including a small market index and they concluded that the excess returns of SRI funds are strongly influenced by the low capitalization of the small cap stocks. The study also shows that SRI funds have a neutral effect on performance. Authors in Reference [19] research US and German mutual funds using a simple regression against an environmental market index, showing that the SRI investments underperform the benchmark in terms of three performance measures (Jensen's alpha, the Treynor ratio, and the Sharpe ratio). In this research, the author used a sample of six US funds and five German SRI Investment funds.

All previous studies used an index as benchmark, so they have the problem of what is the appropriate index. Authors in Reference [4] avoided this problem by using a matched pair analysis to compare SRI mutual funds and conventional funds in the UK. The authors matched 29 SRI mutual funds to conventional ones using the size and the age of the funds as criteria. Their results showed no differences in the performance of both samples using the Sharpe and Treynor ratios as performance measures, but they found that ethical funds did better than the non-ethical funds when the Jensen performance measure was used. Authors in Reference [5] studied 18 SRI funds where the investment area and the fund type were considered. They did not find differences in performance against conventional funds. Authors in Reference [6] studied the performance of 31 US SRI mutual funds and the Domini 400 Social-Index (DSI) from 1990 to 1998. The results show that only some SRI funds could underperform the benchmark (S\&P 500 or DSI). But, in general, SRI funds obtained a similar performance to S\&P 500, DSI, and conventional funds. Authors in Reference [7] used a matching procedure and the age, size, country and investment universe of the fund as variables. The study included mutual funds from Sweden, the Netherlands, Norway, Germany, the UK and Switzerland, and Jensen's alpha and the Sharpe and Treynor ratios as performance metrics. Their results showed that SRI funds' performance was very similar to those of conventional funds. Authors in Reference [8] studied the performance of 30 European SRI funds from four countries, finding that there is no difference between SRI funds and conventional funds. 
The author in Reference [39] studied 42 SRI U.S. mutual funds; he found no evidence of a performance difference between SRI and conventional funds. Both underperformed the Domini 400 Social Index and S\&P 500 during the study period (1994-2001). Authors in Reference [40] investigated the performance of 32 British, 16 German and 55 US SRI funds, they used Jensen and Carhart's alpha and found that German and US SRI mutual funds underperformed in both their relevant indexes and the conventional funds, whereas UK funds slightly outperformed, however the differences were not significant. Authors in Reference [41] investigated the performance of Dutch SRI funds and found that these funds outperformed conventional funds but with no statistically significant difference. Also [42] studied 61 SRI funds tracked by the US Social Investment Forum (USSIF). They found that the relationship between financial and social performance is neither strictly negative, nor strictly positive. Instead, they found a curvilinear relationship, suggesting that the two viewpoints may be complementary. Risk-adjusted performance varies with the types of social screens used. Community relations screening (excludes firms that do not invest in and/or develop economically depressed communities) increased financial performance, but environmental and labor relations screening (excludes firms with a record of poor environmental performance and firms with a record of poor labor relations practices, respectively) decreased financial performance.

Authors in Reference [43] investigated the performance of Australian ethical funds, and [16] invested evidence from Canada, finding no statistical difference in performance between conventional and SRI funds. Study [15] in the UK market, found that neither SRI nor non-SRI funds exhibited significant under performance. Authors in Reference [44] found that SRI funds in the US, the UK, and in many continental European and Asia-Pacific countries underperformed their domestic benchmarks. However, with the exception of France, Japan, and Sweden, the risk-adjusted performance of SRI funds is not statistically different from the performance of conventional funds. Authors in Reference [45] found that during the period 1997-2005, US SRI funds had better performance (gross and net Carhart's alphas) than conventional mutual funds with similar characteristics. Authors found that the differences were driven exclusively by SRI funds run by management companies specializing in SRI, while funds run by companies not specializing in SRI underperform conventional funds.

Authors in Reference [46] compare the investment performance of US environmental or green mutual funds, finding that in the 1987-2009 period, green funds had lower performance levels than conventional funds but, in the period 2001-2009 green funds achieved risk-adjusted returns not significantly different from the rest of SRI and conventional mutual funds. Authors in Reference [47] performed a study focused on 88 SRI funds from the European market from 1996 to 2007 . They concluded that the performance of SRI funds is similar to the performance of both conventional and socially responsible indexes. Authors in Reference [48] studied seven European and US markets from 1996 to 2008. They found in several European markets (Belgium, France, Germany, Italy, the Netherlands, and the UK) that SRI funds showed similar performances compared to both conventional and benchmarks. In contrast, the US and Austrian funds showed evidence of underperformance.

Authors in Reference [49] compared 46 randomly selected US-based large-cap equity mutual funds ( 25 are members of the SIF and 21 are conventional funds) finding there were no significant performance differences between conventional and SRI mutual funds employing Data Envelopment Analysis. They also found that SRI funds underperform at other times. Authors in Reference [50] performed a multi-country study focused on 54 international SRI funds located in eight European markets (Austria, Belgium, France, Germany, Italy, the Netherlands, the UK, and Spain); they applied the five-factor model and found a similar performance between socially responsible funds and conventional funds. Authors in Reference [26] studied 89 European green funds and 18 US funds from 1994 to 2013. They applied the Carhart four-factor model and stated that, for the US market, green funds did not perform any worse than the market, but with a global equity portfolio green funds showed evidence of underperformance. Authors in Reference [51] found no clear-cut dominance over the entire period analyzed (1992-2012), but also found that SRI funds generally did better than conventional funds in the period following the global financial crisis of 2007. Reference [52], focusing on the French 
market, found that SRI funds underperformed slightly more than their matched samples according to different models, but differences in alphas are not statistically significant in most cases. They only found significance in one of the estimated models at the $10 \%$ significance level. Reference [17] found that SRI managers have longer tenure and are more likely to be female, but they did not find any significant difference in the performance of SRI and conventional funds. Authors in Reference [53] conducted a comparative financial performance analysis on European green, conventional, and black mutual funds; they concluded that there was no difference in the performance of the green and the conventional funds and that green funds are beginning to significantly outperform black funds.

Reference [22] is the only reference, to our knowledge, that employs Morningstar Sustainability scores in their analysis. The authors conclude that funds with higher Morningstar Sustainability scores have similar alphas from those with lower sustainability scores. The authors also observe that there is little difference in the performance or sustainability scores between self-proclaimed SRI funds versus those that fall in the top 50 and top 20 percent of Morningstar's Sustainability scores. Finally, [23] employed a CSR score, which is an asset-weighted composite CSR fund score. They showed the effects of CSR on fund performance; compared to low-CSR funds, high-CSR funds displayed a poorer performance. Based on the findings of previous literature regarding SRI investment we propose the following research hypotheses:

Hypothesis 1 (H1). The degree of sustainability of a mutual fund has a positive relation with performance.

Reference [20] found that assets under management (AUM) for SRI mutual funds increased by more than $13 \%$ during 2007-2009, while conventional funds remained relatively flat. References [54,55] obtained evidence in favor of greater stability in flows for SRI funds, while [56] found that SRI mutual funds are more sensitive to positive returns and less to negative ones. Reference [22] concluded that Morningstar Sustainability metrics seems to have no influence on the flows of funds for the US market, but on the contrary, if it has a positive influence for funds self-declares as SRI so they appear to be more attractive to investors. Finally, [23] evidence that high corporate social responsibility (CSR) funds are likely to attract investors that are less sensitive to performance, but the effect of fund CSR on flows' persistence is statistically insignificant. In line with previous literature, we argue that funds with higher ESG scores attract more conscious investors, who are less worried about performance and therefore the flows are less sensitive to past performance:

Hypothesis 2 (H2). The degree of sustainability of a mutual fund has a positive relation with the flow of funds.

Reference [20] found that SRI mutual funds outperformed conventional funds in the global financial crisis, so they can be an optimal choice for investors who want to protect themselves from downside risk. Value at risk (VaR) describes the expected maximum loss over a target horizon within a given confidence level. VaR is an essential tool for communicating downside risk, but there are surprisingly few papers that have used this metric in the study of SRI investment funds (see, e.g., [24]). We propose the following hypotheses:

Hypothesis 3 (H3). The degree of sustainability of a mutual fund has a negative relation with downside risk measured by Value at Risk (VaR).

\section{Empirical Study}

\subsection{Sample}

Our initial sample contained 1690 European equity funds rated by Morningstar Sustainability across the time period 2016-2018. Morningstar Sustainability scores are only available from 2016. We have analyzed the behavior of the sustainability scores data for different monthly observations in 2016, 2017, 2018 and found that the variability of the data for the funds was very small, so we 
employed the average annual data for our unbalanced yearly panel data (2016-2018). The funds are the "open funds" type with an ESG score in the investment area of Euroland, Europe and Europe ex-UK. Furthermore, to avoid problems of multicollinearity, we selected only an equivalent class for each fund. We obtained for each equity mutual fund several measures of performance and other variables such as size, downside deviations, socially conscious, expenses, and age. We also used the Morningstar style-box to control the effect of the different categories which are included in the sample. The number of funds varied when we considered the different variables because of the lack of data available in the database.

\subsection{Variables Construction}

Our sustainability variables were obtained from Morningstar Direct (original source Sustainalytics). We employed the Portfolio Sustainability Score (Sustscore), which is the ESG score minus the Portfolio Controversy Score. Reference [57] examines the process by which Morningstar Sustainability and ESG scores are calculated.

The Morningstar Portfolio Sustainability Score is a measure developed in 2016 for scoring mutual funds and ETFs about ESG risks and opportunities. The subsequent Morningstar Sustainability Rating is a comparison relative to their Morningstar Category peers and is derived from the Morningstar Portfolio Sustainability Score. The Morningstar Portfolio Sustainability Score (Sustscore) is defined as follows [58,59]:

$$
\text { SustScore }=\text { Portfolio ESG Score }- \text { Portfolio Controversy Deduction }
$$

In order to receive a Portfolio Sustainability Score, a portfolio must have a portfolio ESG score and a portfolio controversy score, which, according to [59], at least $50 \%$ of a portfolio's assets under management must have these scores. The Morningstar Portfolio ESG Score (ESGscore) is calculated as:

$$
\text { ESGscore }=\sum_{i=1}^{n} \mathrm{w}_{i} \text { ESGNorm }_{i}
$$

where:

ESGNorm $_{\mathrm{i}}=$ the normalized ESG score of company $i$,

$n=$ the number of securities in the portfolio,

$\mathrm{w}_{i}=$ the asset weight on security $i$, so the sum $\sum_{i=1}^{n} \mathrm{w}_{i}=100 \%$.

Normalized company ESGs are aggregated to a portfolio ESG score using an asset-weighted average of all covered securities. Sustainalytics tracks and categorizes ESG-related incidents in companies, which are called "controversies". A single company may be involved in multiple ESG-related incidents at any given time, so Sustainalytics makes a controversy score of company $i$. Morningstar employs company controversy scores of Sustainalytics, creating a Morningstar Portfolio Controversy Score $\left(\mathrm{MContr}_{p}\right)$, as follows:

$$
\operatorname{MContr}_{p}=\sum_{i=1}^{n} \mathrm{w}_{i} \text { SCont }_{i}
$$

where:

$\mathrm{w}_{i}=$ the asset weight on security $i$,

SCont $_{i}=$ the Sustainalytics controversy score of company $i$.

We considered different performance measures from the Morningstar Direct database (net returns and Sharpe ratios). We also computed Carhart's alphas based on values provided on Kenneth French's website (See http://mba.tuck.dartmouth.edu/pages/faculty/ken.french/data_library.html). 
We also assessed fund performance by considering tail risk. Tail risk is commonly taken by mutual funds and it has been shown to be useful in explaining fund performance. Specifically, we examined whether sustainable mutual funds were more or less exposed to tail risk by measuring mutual fund downside risk by using the Value at Risk (VaR). VaR measures the maximum loss that a fund $i$ can obtain for a given time period and a given confidence level (1-p) as:

$$
\operatorname{Pr}\left(R_{i} \leq \operatorname{Var} R_{i}\right)
$$

which is the loss associated with the $p$-th percentile of the return distribution. It can be computed as $\operatorname{Var}_{i}=F_{i}^{-1}(p)$, where $F_{i}$ is the return distribution of the fund $i$.

We measure the flow of funds as:

$$
\text { Flow }_{i}=\frac{T N A_{i, t}-T N A_{i, t-1}\left(1+R_{i, t}\right)}{T N A_{i, t-1}}
$$

where $T N A_{i, t}$ and $T N A_{i, t-1}$ are the total net assets for fund $i$ at the end of year $t$ and $t-1$, respectively, and $R_{i, t}$ is the return of fund $i$ in year $t$.

\subsection{Descriptive Statistics}

Table 1 shows the different variables considered in our work for the whole sample (2016-2018). As can be seen, the variable related to the level of sustainability have an average level close to 55.5 points for the three years analyzed $(2016,2017,2018)$, and the difference between the minimum and maximum is around 25 points. On average, the funds have a negative one year alpha $(-0.20 \%)$, a one year Sharpe ratio positive $(0.49)$ and a positive net return $(2.23 \%)$. The average flow has been negative $(-0.05 \%$ of the net assets) and the percentage declared to be socially responsible is small (14\%). The size is very variable, the expense ratio (total expense ratio or TER) is greater than $1.5 \%$ because the mutual funds included invest in equity, and in general the funds have a high average age (greater than 12 years measured at the end of the year 2018). Value at risk (VaR) is near to $5.3 \%$ on a monthly basis using a $95 \%$ confidence level and finally the annual volatility of downside deviation is near $7.3 \%$.

Table 1. Descriptive statistics (all data).

\begin{tabular}{cccccc}
\hline Variable & Obs & Mean & Std. Dev. & Min & Max \\
\hline Sustscore & 4295 & 55.51 & 2.93 & 40.26 & 65.32 \\
Alpha & 4763 & -0.20 & 0.54 & -5.84 & 3.71 \\
Sharpe & 4597 & 0.49 & 1.92 & -3.45 & 5.53 \\
Return & 4598 & 2.23 & 19.71 & -40.28 & 72.73 \\
VaR & 4611 & 5.29 & 2.15 & 0.14 & 14.35 \\
Size (millions) & 4805 & 365.00 & 855.00 & 1.07 & $25,000.00$ \\
Downside dev & 3633 & 7.27 & 2.60 & 1.07 & 18.17 \\
Flowasset & 4801 & -0.05 & 2.89 & -73.56 & 160.41 \\
ExpRatio & 4288 & 1.55 & 0.96 & 0.11 & 13.26 \\
Age & 5070 & 12.79 & 9.12 & -0.22 & 62.10 \\
Sociallyconcious & 5070 & 0.14 & 0.35 & 0.00 & 1.00 \\
\hline
\end{tabular}

This table reports the values of the variables considered in the analysis obtained from Morningstar Direct database and authors' calculations. Sustscore is the level of sustainability of the mutual fund. Alpha is the Carhart's alpha measure. Sharpe is the yearly risk-adjusted return. Return is the total net return expressed in USD and value at risk (VaR) a tail risk measure expressed in base currency (euros). Downside dev measures the volatility of downside performance, i.e., for the periods with a loss. Size is the amount invested in millions of dollars. Flowasset is the percentage of new funds over total assets and ExpRatio the total or net expense ratio. Age are the years from inception date measured at the end of 2018 and Sociallyconcious is a dummy that takes the value one when the fund declares itself socially responsible and zero otherwise.

We have divided our sample funds into two groups based on whether the sustainability scores are below or above the median. Then, we estimated the means and their differences between both groups. Table 2 reports the results of the univariate analysis. As can be observed, the differences are very significant 
between the two groups for the different scores, with a difference of approximately four points in favor of the funds included in the high score group. The differences in performance between the high and low sustainability scored funds are positive when considering net returns, Sharpe ratios and alphas but statistically insignificant (Table 2). That is, higher sustainability scored funds show a greater performance. Our results are contrary to the findings of $[22,23]$ for US mutual funds. Table 2 also shows the difference of means for tail risk measured by the VaR at a $95 \%$ confidence level. The evidence for VaR reveals that highly scored mutual funds display less tail risk. Finally, Table 2 displays the difference of means for the flow of funds showing positive differences for higher scored mutual funds.

Table 2. Mean values for different groups.

\begin{tabular}{cccc}
\hline Variable & Low ESG Score & High ESG Score & t-Statistic \\
\hline \multicolumn{5}{c}{ Sustainability Scores } \\
\hline Sustscore & 53.40 & 57.59 & $-4.44^{* * *}$ \\
\hline \multicolumn{5}{c}{ Performance } \\
\hline Alpha & -0.2038 & -0.2004 & 0.0034 \\
Return & 1.1707 & 1.1944 & 0.0237 \\
Sharpe & 0.3480 & 0.4462 & 0.0982 \\
\hline \multicolumn{5}{c}{ Downside risk } \\
\hline VaR & 5.3981 & 5.3388 \\
\hline \multicolumn{5}{c}{ Flows } \\
\hline Flowasset
\end{tabular}

This table reports the values of sustainability variables, performance metrics, VaR values and the the values of flow of funds considered in the analysis obtained from Morningstar direct database and own calculations. The funds are classified into low or high groups depending on whether their score is above or below the median. The two-tailed t-statistic for difference of means is reported in the third column. Sustscore is the level of sustainability of the mutual fund measured by Morningstar. Alpha (Carhart's alpha) and Sharpe (Sharpe ratio) are risk adjusted returns calculated at the end of 2016, 2017 and 2018. Return is the net measure of profitability. The data has been obtained from Morningstar Direct database and Kenneth French's website. VaR is the yearly value at risk measured at the end of 2016, 2017 and 2018. Flowasset_year is the percentual flow relative to assets of the mutual funds. ${ }^{* * *}$ Significant at $1 \%$.

Table 3 compares the funds self-declared sustainable (Sociallyconscious) and those that result from dividing the sample according to a low Sustscore or a high Sustscore criteria $(0$ and 1 in the Sustainabledummy variable, respectively). As you can see, there are big differences but, in general, mutual funds that are self-declared sustainable (Sociallyconcious $=1$ ) are from a Sustscore point of view too (Sustainabledummy $=1$ ). However, there are many funds that are not declared sustainable but they are based on the level of sustainability of the companies of their portfolio. Thus, by using scores, investors have at their disposal a large number of funds that are not declared sustainable but with comparable portfolios of self-declared sustainable funds. This result is similar to [22] for the US market.

Table 3. Sustainability and environmental, social and corporate governance (ESG) scores for different groups.

\begin{tabular}{cccc}
\hline & \multicolumn{2}{c}{ Sustainabledummy } & \multirow{2}{*}{ Total } \\
\cline { 1 - 3 } Sociallyconcious & $\mathbf{0}$ & $\mathbf{1}$ & \\
\hline 0 & 1950 & 1723 & 3673 \\
1 & 195 & 427 & 622 \\
Total & 2145 & 2150 & 4295 \\
\hline
\end{tabular}

This table reports the number of mutual funds classified as sustainable using two different dummy variables. Sustainabledummy is based on low or high sustainable scores depending on whether their score is above (value 1) or below the median (value 0 ). Sociallyconscious is for those mutual funds declared as socially conscious investment or SRI mutual fund (value 1). 


\subsection{Fund Performance and Sustainability Scores}

In this part, we tested if the degree of sustainability measured through ESG scores had a positive or negative relation with performance. In addition, we considered ESG scores to evaluate the contribution of each dimension to the portfolio performance. We propose the following model:

$$
\begin{gathered}
Y_{i, t}=\text { cons }_{i}+\beta_{1} \text { Sustscore }_{i, t-h}+\beta_{2} \text { Age }_{i}+\beta_{3} \text { DownsideDev }_{i, t}+\beta_{4} \log \text { SIZE }_{i, t}+\beta_{5} \text { ExpRat }_{i, t} \\
+\beta_{6} \text { Sociallyconcious }_{i, t}+\sum_{j} \text { Category }_{j, t}+\varepsilon_{i, t}
\end{gathered}
$$

where:

$Y_{i, t}=$ Alternative performance metrics for fund $i$ in time $t$ (years 2016, 2017 and 2018).

$i=1$ through $\mathrm{N}$, where $\mathrm{N}$ is the total number of funds in the sample.

Sustscore $_{i}$ is the sustainability score provided by Morningstar. We tested the effects of this variable on performance for time $t$ and $t-1(\mathrm{~h}=1)$.

Age $=$ Years since inception date measured at the end of the year 2018.

Downside dev $=$ measures the volatility of downside performance.

LogSize $=$ logarithm of mutual fund market value.

ExpRat $=$ Net expense ratio of fund $i$.

Sociallyconcious = dummy of self-proclaimed SRI mutual funds.

Category $=$ dummies of Morningstar categories except small style.

cons $_{i}$ and $\beta_{1}, \beta_{2}, \beta_{3}$, and $\beta_{4}$ are parameters of the regression and $\varepsilon_{i, t}$ the term error.

Our results show that Sustscore is significant in explaining the level of performance for all the metrics with the exception of alpha in time $t$. The dummy variable (SociallyConcious) is also significant in time $t$ models, showing that considering the level of sustainability can help to better understand the relationship between performance and social responsibility. Our results support [21], who conclude that the lack of clearly defined criteria to distinguish mutual funds as socially responsible affects the results of previous research based on dichotomy variables (self-proclaimed SRI mutual funds versus others). Among the control variables, Table 4 shows that the expense ratio are always negatively related to performance, while size and age (except in return models) are not significant.

Table 4. Sustainability scores and fund performance.

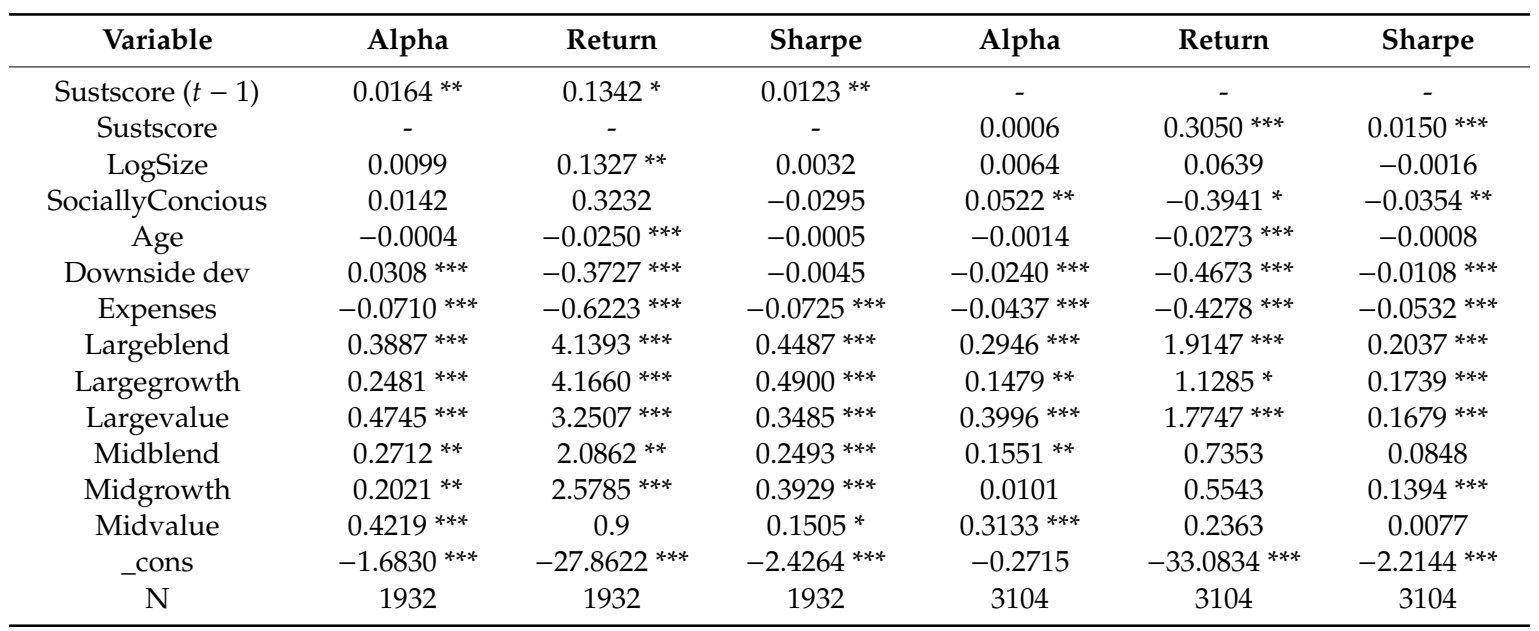

This table reports the coefficients for the regression models for different performance measures. Alpha is the Carhart's alpha measure; Sharpe is the yearly risk-adjusted return and Return is the total net return. Sustscore is the level of sustainability of the fund provided by Morningstar and Sociallyconcious is the common dummy variable used to analyse self-declared socially conscious mutual funds. logSize is the logarithm of mutual fund market value. ExpRatio the net expense ratio and age are the years from inception date. Downside dev measures the volatility of downside performance. $\mathrm{N}$ is the number of observations. The dummies of categories have been included and compared with small mutual fund of Morningstar Style Box. * Significant at $10 \%$; ** significant at $5 \%$ and ${ }^{* * *}$ significant at $1 \%$. 


\subsection{Tail Risk and Sustainability Scores}

In this part, we tested if the degree of sustainability measured through sustainability scores had a positive or negative relation with the VaR of the portfolio.

We used the following model:

$$
\begin{aligned}
\operatorname{VaR}_{i, t}=\text { cons }_{i}+\quad & \beta_{1} \text { Sustscore }_{i, t-h}+\beta_{2} \text { Age }_{i}+\beta_{3} \text { DownsideDev }_{i, t}+\beta_{4} \log \text { SIZE }_{i, t} \\
& +\beta_{5} \text { ExpRat }_{i, t}+\beta_{6} \text { Sociallyconcious }_{i, t}+\sum_{j} \text { Category }_{j, t}+\varepsilon_{i, t}
\end{aligned}
$$

As Table 5 shows, the tail risk of mutual funds is affected by the level of sustainability, we again tested the effects of this variable on performance for time $t$ and $t-1(\mathrm{~h}=1)$. Specifically, we observed how the variable Sustscore was negatively and significantly related to the VaR of the fund at a 95\% confidence. These results support that funds with a higher degree of sustainability better protect investors against extreme losses. As [36,37] explain, SRI mutual fund managers base their decisions on deeper, more complete, and higher quality information, resulting in a significant reduction in the risk of their investment decisions. On the other hand, the dichotomous variable commonly used has a positive sign. and opposite sign to that resulting from using a continuous variable. From this analysis, we observed that the results of evaluating the effect of sustainability based on dichotomous variables may yield contradictory results to those obtained when continuous variables are used.

Table 5. Sustainable score and downside risk.

\begin{tabular}{ccc}
\hline Variable & VaR & VaR \\
\hline Sustscore $(t-1)$ & $-0.0310^{* *}$ & - \\
Sustscore $(t)$ & - & $-0.0546^{* * *}$ \\
LogSize & $-0.0553^{* * *}$ & $-0.0546^{* * *}$ \\
SociallyConcious & $0.0921^{*}$ & $0.1210^{* *}$ \\
Age & $0.0102^{* * *}$ & $0.0138^{* * *}$ \\
Expenses_ & -0.0093 & $-0.0273^{* *}$ \\
Largeblend & $-0.5178^{* * *}$ & $-0.8081^{* * *}$ \\
Largegrowth & $-0.4481^{* * *}$ & $-0.7883^{* * *}$ \\
Largevalue & $-0.3114^{* * *}$ & $-0.4983^{* * *}$ \\
Midblend & $-0.2201^{* *}$ & $-0.4854^{* *}$ \\
Midgrowth & -0.0716 & $-0.2814^{* *}$ \\
Midvalue & $0.1458^{* *}$ & $-0.0984^{* *}$ \\
_cons & $9.8708^{* * *}$ & $11.3831^{* * *}$ \\
N & 2290 & $3709^{*}$
\end{tabular}

This table reports the coefficients for the regression models. VaR is the maximum loss that a fund $i$ can obtain for a given time period $t$ and a given confidence level. Sustscore is the level of sustainability of the mutual fund measured by Morningstar. Sociallyconcious is a dummy variable used to analyze self-declared SRI mutual funds. logSize is the logarithm of mutual fund market value. ExpRatio the net expense ratio and Age are the years from inception date. The dummies of categories have been included and compared with small mutual fund of Morningstar Style Box. $\mathrm{N}$ is the number of observations. ${ }^{*}$ Significant at $10 \% ;{ }^{* *}$ significant at $5 \%$ and ${ }^{* * *}$ significant at $1 \%$.

\subsection{Flows and Sust ainability Scores}

In this section, we analyze the effect of sustainability on the flows of investment funds. In particular, flows of sustainable funds are generally considered to be less sensitive to changes in performance because investors value other elements in their utility function. References $[54,55]$ obtained evidence in favor of greater stability in flows for sustainable funds, while [56] found that SRI mutual funds are more sensitive to positive returns and less to negative ones. In line with [22,23], we argue that funds with higher ESG scores attract more conscious investors, who are less worried about performance and therefore the flows are less sensitive to past performance. Thus, we estimate the following model to evaluate the effect of sustainability on the flow of funds using the different performance metrics (alpha, 
Sharpe, net return), the sustainability score, and the interaction of the product (SustPerf: sustsharpe, sustalpha or sustreturn):

$$
\begin{array}{r}
\text { Flow }_{i, t}=\alpha_{i, t}+\quad \begin{array}{r}
\beta_{1} \text { Performance }_{i, t}+\beta_{2} \text { Sustscore }_{i, t} h+\beta_{3} \text { SustPerf }_{i, t}+\beta_{4} \text { Age }_{i} \\
+ \\
+\beta_{5} \text { Downside }_{i, t}+\beta_{6} \log \text { SIZE }_{i, t}+\beta_{7} \text { ExpRatio }_{i, t} \\
+\beta_{8} \text { Sociallyconcious }_{i, t}+\sum_{j} \text { Category }_{j, t}+\varepsilon_{i}
\end{array}
\end{array}
$$

where:

SustPerf $f_{i, t}$ : is the product of Sustscore and sharpe (Sustsharpe), alpha (Sustalpha) or net return (Sustreturn) depending on the model for mutual fund $i$ and time period $t$.

Table 6 shows that the models that takes the Sharpe ratio as the performance variable (Models 3 and 4 ) $\beta_{1}$ is not significant. The results are mixed in the case of the net returns (Models 5 and 6), but $\beta_{1}$ is very significant when risk-adjusted performance is measured by Carhart's alpha (Models 1 and 2), which means that performance had an influence on investment decisions (flows). On the other hand, in Model 5 , the sustainability score is also significant, so that higher-rated funds received a larger volume of funds than those with a lower score. This fact shows that the degree of sustainability stimulates fund raising and more when the degree of sustainability is higher. Also, when we analyzed the effect of the sustainability dummy variable (Sociallyconcious), it was not significant in all models, which was contrary to the hypothesis of the importance of sustainability in attracting investors interested in funds that are self-declared as SRI. Finally, the negative sign of the interaction variable (Sustalpha in Models 1 and 2) shows the lower sensitivity of sustainable funds, supporting the results found by [22,23] using alternative metrics and US funds. This fact can be related to greater social awareness in SRIs.

Table 6. Sustainability score and flow of funds.

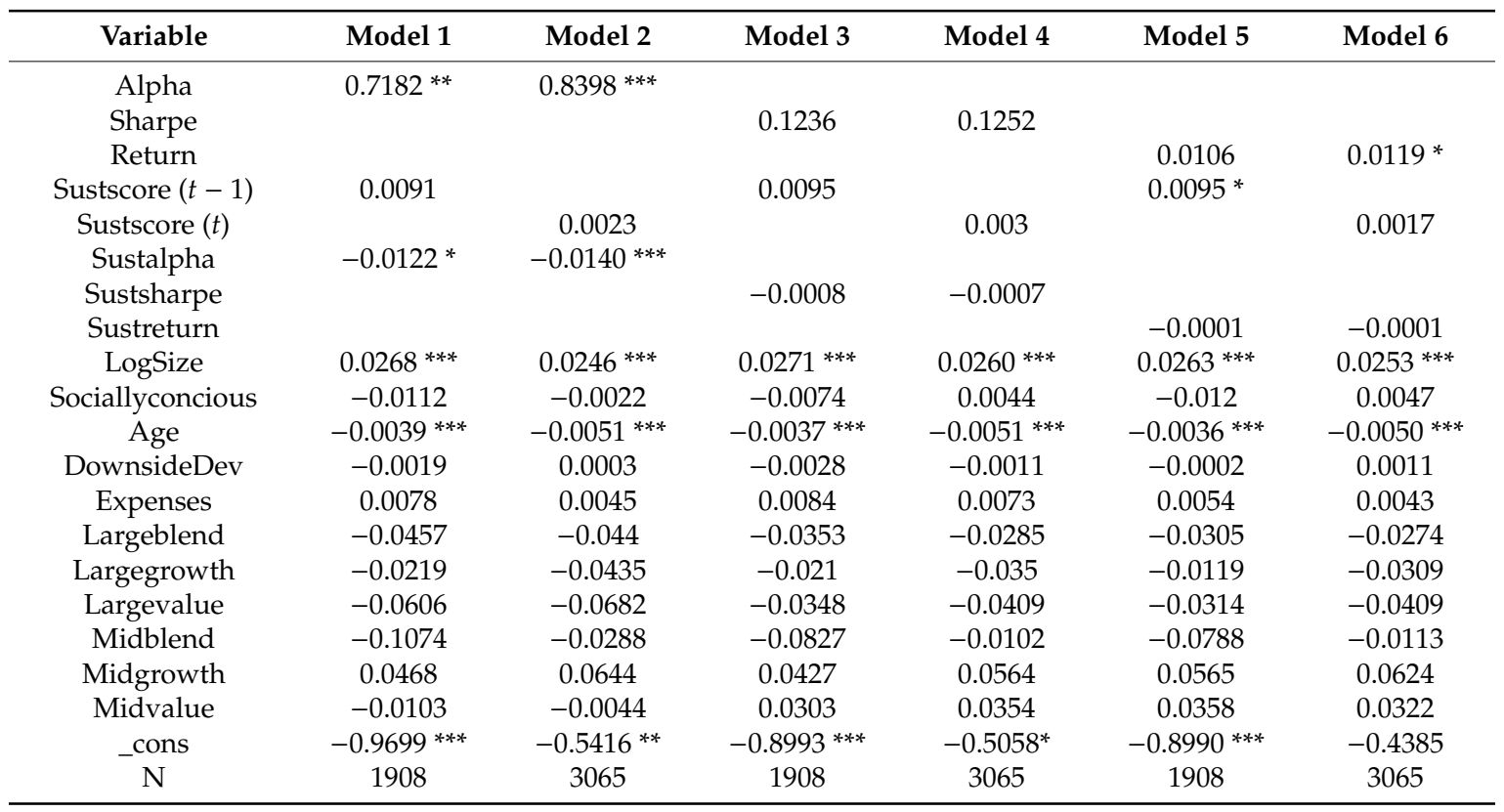

This table reports the coefficients for the regression models. Alpha is the Carhart's alpha measure; Sharpe is the yearly risk-adjusted return and, Return is the total net return. Sustscore is the level of sustainability of the mutual fund measured by Morningstar. Sociallyconcious is a dummy variable used to analyze socially conscious mutual funds. logSize is the logarithm of mutual fund market value. ExpRatio the net expense ratio and Age are the years from inception date. DownsideDev measures the volatility of downside performance. The dummies of categories have been included and compared with small mutual fund of Morningstar Style Box. N is the number of observations. ${ }^{*}$ Significant at $10 \% ;{ }^{* *}$ significant at $5 \%$ and ${ }^{* *}$ significant at $1 \%$. 


\section{Robustness}

We conducted some additional robustness tests to check the consistency of our results and to provide other complementary analyses. First, we also calculated the models excluding the Downside deiation because this variable has many blanks and reduces the sample. After the calculations, we again observed no differences with the models presented in the previous empirical analyses.

Second, we checked whether performance may differ according to the fund manager skills, considering the quantiles of different performance measures; differences in the quantiles would indicate differences in the fund manager's ability to deal with performance. Quantile regression allowed us to capture information about the coefficients at different quantiles of the dependent variable given the set of endogenous variables. In addition, the conditional quantile regression developed by [60] successfully deals with skewed distributions of fund performance. In particular, we adopted the bootstrapping method proposed by [61] and implemented in the software Stata 12. Given $y_{i}$ as the different performance metrics used in this paper (alpha, Sharpe and returns), and $X_{i}$ as a vector of exogenous variables representing the sustainable score of each mutual fund and other controls, the quantile model can be written as:

$$
y_{i}=X_{i}^{\prime} \beta_{\phi}+u_{\phi i}
$$

Assuming that:

$$
\begin{gathered}
\operatorname{Quant}_{\phi}\left(y_{i} \mid X_{i}\right)=X_{i}^{\prime} \beta_{\phi} \\
\operatorname{Quant}_{\phi}\left(u_{\phi i} \mid X_{i}\right)=0
\end{gathered}
$$

Table 7 reports quantile parameter estimates for three different metrics. Our evidence for all quantiles confirms no differences in the results and sustainability (in time $t$ and also in time $t-$ 1 except for alpha) seems to be important variable to explain the performance independent of the metric analyzed.

Finally, we recalculated the models for each category (Largeblend, Largegrowth, Largevalue, Midblend, Midgrowth, Midvalue and Small) and we obtained small different results depending on the

\begin{tabular}{|c|c|c|c|c|c|c|}
\hline & Alpha & Return & Sharpe & Alpha & Return & Sharpe \\
\hline \multicolumn{7}{|c|}{$q 25$} \\
\hline Sustscore $(t-1)$ & $0.0178 *$ & $1.3874^{* * *}$ & $0.1376^{* * *}$ & & & \\
\hline Sustscore $(t)$ & & & & 0.0008 & $0.7672^{* * *}$ & $0.0631^{* * *}$ \\
\hline LogSize & 0.0141 ** & $0.8115^{* * *}$ & $0.0729^{* * *}$ & 0.0034 & $0.7381^{* * *}$ & $0.0533^{* * *}$ \\
\hline Sociallyconcious & 0.0153 & 0.6148 & 0.034 & -0.0368 & $1.7221^{* * *}$ & $0.1006^{* * *}$ \\
\hline Age & -0.0005 & $-0.0952 * * *$ & $-0.0054^{* *}$ & -0.0012 & $-0.0790 * * *$ & $-0.0051^{* * *}$ \\
\hline DownsideDev & $0.0361^{* * *}$ & $-4.2144^{* * *}$ & $-0.3316^{* * *}$ & $-0.0462^{* * *}$ & $-0.9440^{* * *}$ & $-0.0277^{* *}$ \\
\hline Expenses & $-0.0976^{* * *}$ & $5.0137^{* * *}$ & $0.5087^{* * *}$ & $-0.1083^{* * *}$ & $3.7596^{* * *}$ & $0.2712^{* * *}$ \\
\hline _cons & $-2.2790^{* * *}$ & $-88.6161^{* * *}$ & $-8.8093 * * *$ & -0.4525 & $-72.3824^{* * *}$ & $-6.0500^{* * *}$ \\
\hline \multicolumn{7}{|c|}{ q50 } \\
\hline Sustscore $(t-1)$ & $0.0209^{* * *}$ & $2.1667^{* * *}$ & $0.2188^{* * *}$ & & & \\
\hline Sustscore $(t)$ & & & & -0.0029 & $1.6002^{* * *}$ & $0.1210^{* * *}$ \\
\hline LogSize & 0.0063 & $1.0241 * * *$ & $0.0902^{* * *}$ & -0.0082 & $1.5147^{* * *}$ & $0.1199^{* * *}$ \\
\hline Sociallyconcious & $0.0605^{* *}$ & -1.1406 & -0.1181 & 0.0238 & $3.0024 * *$ & $0.4049^{* * *}$ \\
\hline Age & -0.0013 & -0.0763 & -0.007 & $-0.0018^{*}$ & $-0.1082^{* *}$ & $-0.0086^{* * *}$ \\
\hline DownsideDev & $0.0437^{* * *}$ & $-5.6356^{* * *}$ & $-0.5014^{* * *}$ & $-0.0280^{* * *}$ & $-2.8355^{* * *}$ & $-0.2512^{* * *}$ \\
\hline Expenses & $-0.0799^{* * *}$ & $6.0189^{* * *}$ & $0.6518^{* * *}$ & $-0.0929^{* * *}$ & $7.7501^{* * *}$ & $0.7143^{* * *}$ \\
\hline _cons & $-1.9249^{* * *}$ & $-118.6429^{* * *}$ & $-11.8506^{* * *}$ & 0.142 & $-111.7050^{* * *}$ & $-8.4958^{* * *}$ \\
\hline
\end{tabular}
category, concluding that on average the effect is positive on performance but specific for each category.

Table 7. Quantile regression. 
Table 7. Cont.

\begin{tabular}{|c|c|c|c|c|c|c|}
\hline & Alpha & Return & Sharpe & Alpha & Return & Sharpe \\
\hline Sustscore $(t-1)$ & 0.0133 & $2.5735^{* * *}$ & $0.2399 * * *$ & & & \\
\hline Sustscore $(t)$ & & & & -0.0044 & $1.6236^{* * *}$ & $0.1333^{* * *}$ \\
\hline LogSize & -0.0027 & $0.9934^{* * *}$ & $0.1198^{* * *}$ & -0.0142 & $1.3970 * * *$ & $0.1340^{* * *}$ \\
\hline Sociallyconcious & 0.0236 & -1.9445 & -0.2386 & 0.0397 & -0.1055 & -0.0315 \\
\hline Expenses & $-0.0478^{* *}$ & $4.9097^{* * *}$ & $0.5176^{* * *}$ & $-0.0909 * * *$ & $5.1538^{* * *}$ & $0.5520 * * *$ \\
\hline _cons & -0.9603 & $-126.2096^{* * *}$ & $-12.2008^{* * *}$ & 0.5931 & $-81.6912^{* * *}$ & $-6.1260^{* * *}$ \\
\hline $\mathrm{N}$ & 1932 & 1932 & 1932 & 3104 & 3104 & 3104 \\
\hline
\end{tabular}

This table reports the coefficients for the quantile regression models (q25 or lower quartile, q50 or median and q75 or upper quartile). Sustscore is the level of sustainability of the mutual fund measured by Morningstar. Sociallyconcious is a dummy variable used to analyse socially conscious mutual funds. logSize is the logarithm of mutual fund market value. ExpRatio the net expense ratio and Age are the years from inception date. DownsideDev measures the volatility of downside performance. Category dummies are omitted in the table. $\mathrm{N}$ is the number of observations. ${ }^{*}$ Significant at $10 \%$; ${ }^{* *}$ significant at $5 \%$ and ${ }^{* * *}$ significant at $1 \%$.

\section{Discussion}

In Europe, SRI strategies grew by $11.7 \%$ from 2014 to 2016 to reach $\$ 12.04$ trillion [1]. Traditional studies focus their work on mutual funds which declare themselves as funds that support an SRI approach. One important limitation of this approach is that results could be biased, because SRI mutual funds could have different levels of sustainability and differences with conventional funds may not be significant. Recently, Morningstar launched the Morningstar Sustainability Score to classify mutual funds. The use of sustainability scores in our work allows us to evaluate the effect of the degree of sustainability on performance, risk, or flows on European equity mutual funds.

Our results show that there are a large number of funds that are not declared sustainable but their portfolio is comparable to sustainable mutual funds. Furthermore, a sustainability score is significant, explaining the level of performance for all the metrics analysed (Carhart's alpha, Sharpe, and net return), and has positive sign. Using a conventional dummy to declare social mutual funds, the results are significant but with the contrary sign, showing that considering the level of sustainability can help to better understand the link between performance and social responsibility. Our results are in accordance with [21], who concluded that the lack of clearly defined criteria to distinguish SRI mutual funds affected the results. Also, we obtained contrary results to [23] for the US mutual funds market.

In terms of tail risk, the level of sustainability is negatively and significantly related to the VaR of the fund, supporting that higher scored mutual funds better protect against extreme losses. The opposite is found for the conventional dummy, showing the advantages of employing a quantitative measure of sustainability to evaluate assets' risk. This result could mean that SRI mutual fund managers base their decisions on a deeper analysis resulting in a significant reduction in the risk of their investment decisions. Our work shows that sustainability scores can be used by investors worried by extreme losses and not only by values-motivated investors.

Finally, we analyzed the effect of sustainability on the flows, confirming the importance of sustainability in attracting investors. The effect of the sustainability dummy variable is not significant in all models. Carhart's alphas have a positive influence on investment decisions. The sustainability score in the last year is significant on the flows in one model analyzed, so higher-rated funds received a larger volume of funds. Finally, the negative sign of the interaction variable (product of sustainability and alphas) shows the lower sensitivity of sustainable funds. This shows the different sensitivity to performance of values-motivated investors.

As a limitation of our paper, we employ VaR measure as a proxy for tail risk. In the literature, the use of other measures like TailVaR, etc. is frequently employed. We have not analyzed the effects employing these alternative metrics. Another limitation is that we employ an unbalanced 3-year data panel data in our panel, in 2016 Morningstar began reporting Morningstar Sustainability scores and 
not all data is available for all funds and years. Future research will benefit from the increasing amount of data to make empirical studies based on sustainability criteria. Another limitation of our work is that there may be some survivorship bias, but since our sample only includes three years, this bias must be very small.

Author Contributions: The authors equally contributed to the development of this research. Conceptualization: L.O.-G. Data curation: P.D.-S. and L.O.-G. Formal analysis: P.D.-S., L.O.-G., and J.C.R. Investigation: P.D.-S. and R.H.C.-D. Methodology: L.O.-G., and J.C.R. Project administration: P.D.-S. Resources: L.O.-G., and J.C.R. Software: L.O.-G. Supervision: P.D.-S. Validation: P.D.-S., L.O.-G., and J.C.R. Visualization: L.O.-G., and R.H.C.-D. Writing—original draft: R.H.C.-D. Writing—review and editing: P.D.-S., L.O.-G., R.H.C.-D. and J.C.R.

Funding: This research was funded by (1) the Galician Regional Government ED431B 2017/34 and ED431D 2017/19 co-funded by the European Regional Development Fund (ERDF/FEDER) within the period 2014-2020 and (2) the Ministry of Science, Innovation and Universities (MCIU), the Spanish State Research Agency (AEI) and European Regional Development Fund (RTI2018-100702-B-I00 MCIU/AEI/FEDER, UE).

Conflicts of Interest: The authors declare no conflict of interest.

\section{References}

1. GSIA. 2016 Global Sustainable Investment Review. Available online: https://www.msci.com/esg-fund-metrics (accessed on 21 August 2017).

2. Bilbao-Tero, A.; Álvarez-Otero, C.; Bilbao-Tero, C.; Fernández, V.C. Hedonic Evaluation of the SRI Label of Mutual Funds Using Matching Methodology. Int. Rev. Financ. Anal. 2017, 52, 213-227. [CrossRef]

3. Barreda-Tarrazona, I.; Matallín-Saez, J.; Balaguer-Franc, M. Measuring Investors' Socially Responsible Preferences in Mutual Funds. J. Bus. Ethics 2011, 103, 305-330. [CrossRef]

4. Mallin, C.A.; Saadouni, B.; Briston, R.J. The Financial Performance of Ethical Investment Funds. J. Bus. Financ. Account. 1995, 22, 483-496. [CrossRef]

5. Gregory, A.; Matatko, J.; Luther, R. Ethical Until Trust Financial Performance: Small Company Effects and Fund Size Effects. J. Bus. Financ. Account. 1997, 24, 705-725. [CrossRef]

6. Statman, M. Socially Responsible Mutual Funds. Financ. Anal. J. 2000, 56, 30-39. [CrossRef]

7. Kreander, N.; Gray, R.H.; Power, D.M.; Sinclair, C.D. The Financial Performance of European Ethical Funds 1996-1998. J. Account. Financ. 2002, 1, 3-22.

8. Kreander, N.; Gray, R.H.; Power, D.M.; Sinclair, C.D. Evaluating the Performance of Ethical and Non-Ethical Funds: A Matched Pair Analysis. J. Bus. Financ. Account. 2005, 32, 1465-1493. [CrossRef]

9. Friede, G.; Busch, T.; Bassen, A. ESG and Financial Performance: Aggregated Evidence from More Than 2000 Empirical Studies. J. Sustain. Financ. Investig. 2015, 5, 210-233. [CrossRef]

10. Lewis, A.; Mackenzie, C. Morals, Motives and Money: The Case of U.K. Ethical Investing. Hum. Relat. 2000, 53, 179-191. [CrossRef]

11. Webley, P.; Lewis, A.; Mackenzie, C. Commitment Among Ethical Investors: An Experimental Approach. J. Econ. Psychol. 2001, 22, 27-42. [CrossRef]

12. Junkus, J.; Berry, T.D. Socially Responsible Investing: A Review of the Critical Issues. Manag. Financ. 2015, 41, 1176-1201. [CrossRef]

13. Luther, R.G.; Matatko, J.; Corner, D.C. The Investment Performance of UK 'Ethical' Unit Trusts. Account. Audit. Account. J. 1992, 5, 57-70. [CrossRef]

14. Hamilton, S.; Jo, H.; Statman, M. Doing Well While Doing Good? The Investment Performance of Socially Responsible Mutual Funds. Financ. Anal. J. 1993, 49, 62-66. [CrossRef]

15. Gregory, A.; Whittaker, J.M. Performance and Performance Persistence of Ethical Unit Trusts in the UK. J. Bus. Financ. Account. 2007, 34, 1327-1344. [CrossRef]

16. Bauer, R.; Derwall, J.; Otten, R. The Ethical Mutual Fund Performance Debate: New Evidence from Canada. J. Bus. Ethics 2007, 70, 111-124. [CrossRef]

17. Humphrey, J.E.; Warren, G.J.; Boon, J. What is Different about Socially Responsible Funds? A Holdings-Based Analysis. J. Bus. Ethics 2016, 138, 263-277. [CrossRef]

18. Syed, A.M. Socially Responsible: Are They Profitable? Res. Int. Bus. Financ. 2017, 42, 1504-1515. [CrossRef]

19. White, M. The Performance of Environmental Mutual Funds in the United States and Germany: Is There Economic Hope for "Green" Investors? Res. Corp. Soc. Perform. Policy 1995, 1, 323-344. 
20. Nofsinger, J.; Varma, A. Socially Responsible Funds and Market Crises. J. Bank. Financ. 2014, 48, 180-193. [CrossRef]

21. Statman, M.; Glushkov, D. Classifying and Measuring the Performance of Socially Responsible Mutual Funds. J. Portf. Manag. 2016, 42, 140-151. [CrossRef]

22. Dolvin, S.D.; Fulkerson, J.A.; Krukover, A. Do 'Good Guys' Finish Last? The Relationship between Morningstar Sustainability Ratings and Mutual Fund Performance. Available online: https://ssrn.com/ abstract=3019403 (accessed on 22 September 2017).

23. El Ghoul, S.; Karoui, A. Does Corporate Social Responsibility Affect Mutual Fund Performance and Flows? J. Bank. Financ. 2017, 77, 53-63. [CrossRef]

24. Reboredo, J.; Quintela, M.; Otero, L.A. Do Investors Pay a Premium for Going Green? Evidence from Alternative Energy Mutual Funds. Renew. Sustain. Energy Rev. 2017, 73, 512-520. [CrossRef]

25. Glode, V. Why Mutual Funds “Underperform”. J. Financ. Econ. 2011, 99, 546-559. [CrossRef]

26. Muñoz, F.; Vargas, M.; Marco, I. Environmental Mutual Funds: Financ. Performance and Managerial Abilities. J. Bus. Ethics 2014, 124, 551-569. [CrossRef]

27. Rivoli, P. Making a Difference or Making a Statement? Finance Research and Socially Responsible Investment. Bus. Ethics Q. 2003, 13, 271-287. [CrossRef]

28. Rudd, A. Social Responsibility and Portfolio Performance. Calif. Manag. Rev. 1981, 23, 55-61. [CrossRef]

29. Hill, R.P.; Ainscough, T.; Shank, T.; Manullang, D. Corporate Social Responsibility and Social Responsible Investing: A Global Perspective. J. Bus. Ethics 2007, 70, 165-174. [CrossRef]

30. Chegut, A.; Schenk, H.; Scholtens, B. Assessing SRI Fund Performance Research: Best Practices in Empirical Analysis. Sustain. Dev. 2011, 19,77-94. [CrossRef]

31. CFA Institute. Environmental, Social, and Governance Issues in Investing: A Guide for Investment Professionals. Available online: http://www.cfapubs.org/doi/pdf/10.2469/ccb.v2015.n11.1 (accessed on 18 August 2017).

32. Margolis, J.D.; Elfenbein, H.A.; Walsh, J.P. Does it Pay to be Good? A Meta-Analysis and Redirection of Research on the Relationship between Corporate Social and Financial Performance. Available online: https://ssrn.com/abstract=1866371. (accessed on 8 August 2017).

33. Flammer, C. Does Corporate Social Responsibility Lead to Superior Financial Performance? A Regression Discontinuity Approach. Manag. Sci. 2015, 61, 2549-2568. [CrossRef]

34. Humphrey, J.; Tan, D.T. Does it Really Hurt to be Responsible? J. Bus. Ethics 2014, 122, 375-386. [CrossRef]

35. Trinks, P.J.; Scholtens, B. The Opportunity Cost of Negative Screening in Socially Responsible Investing. J. Bus. Ethics 2017, 140, 193-208. [CrossRef]

36. Kurtz, L. The Impact of Social Screening on Growth-Oriented Investment Strategies. J. Perform. Meas. 1997, 65-71.

37. Goldreyer, E.; Diltz, D. The Performance of Socially Responsible Mutual Funds: Incorporating Sociopolitical Information in Portfolio Selection. Manag. Financ. 1999, 25, 23-36. [CrossRef]

38. Luther, R.; Matatko, J. The Performance of Ethical Unit Trusts: Choosing an Appropriate Benchmark. Br. Account. Rev. 1994, 26, 77-89. [CrossRef]

39. Bello, Z.Y. Socially Responsible Investing and Portfolio Diversification. J. Financ. Res. 2005, 28, 41-57. [CrossRef]

40. Bauer, R.; Koedijk, K.; Otten, R. International Evidence on Ethical Mutual Fund Performance and Investment Style. J. Bank. Financ. 2005, 29, 1751-1767. [CrossRef]

41. Scholtens, B. Style and Performance of Dutch Social Responsible Investment Funds. J. Investig. 2005, 14, 63-72. [CrossRef]

42. Barnett, M.L.; Salomo, R.M. Beyond Dichotomy: The Curvilinear Relationship between Social Responsibility and Financial Performance. Strat. Manag. J. 2006, 27, 1101-1122. [CrossRef]

43. Bauer, R.; Otten, R.; Rad, A.T. Ethical Investing in Australia: Is There a Financial Penalty? Pacific-Basin Financ. J. 2006, 14, 33-48. [CrossRef]

44. Renneboog, L.; Ter Horst, J.; Zhang, C. The Price of Ethics and Stakeholder Governance: The Performance of Socially Responsible Mutual Funds. J. Corp. Financ. 2008, 14, 302-322. [CrossRef]

45. Gil-Bazo, J.; Ruiz-Verdú, P.; Santos, A. The Performance of Socially Responsible Mutual Funds: The Role of Fees and Management Companies. J. Bus. Ethics 2010, 94, 243-263. [CrossRef] 
46. Climent, F.; Soriano, P. Green and Good? The Investment Performance of US Environmental Mutual Funds. J. Bus. Ethics 2011, 103, 275-287. [CrossRef]

47. Cortez, M.C.; Silva, F.; Areal, N. The Performance of European Socially Responsible Funds. J. Bus. Ethics 2011, 87, 573-588. [CrossRef]

48. Cortez, M.C.; Silva, F.; Areal, N. Socially Responsible Investing in the Global Market: The Performance of US and European Funds. Int. J. Financ. Econ. 2012, 17, 254-271. [CrossRef]

49. Pérez-Gladish, B.; Méndez Rodríguez, P.; M'Zali, B.; Lang, P. Mutual Funds Efficiency Measurement Under Financial and Social Responsibility Criteria. J. Multi-Criteria Decis. Anal. 2013, 20, 109-125. [CrossRef]

50. Leite, P.; Cortez, M.C. Style and Performance of International Socially Responsible Funds in Europe. Res. Int. Bus. Financ. 2014, 30, 248-267. [CrossRef]

51. Becchetti, L.; Ciciretti, R.; Dalo, A.; Herzel, S. Socially Responsible and Conventional Investment Funds: Performance Comparison and the Global Financial Crisis. Appl. Econ. 2015, 47, 2541-2562. [CrossRef]

52. Leite, P.; Cortez, M.C. Performance of European Socially Responsible Funds during Market Crises: Evidence from France. Int. Rev. Financ. Anal. 2015, 40, 132-141. [CrossRef]

53. Ibikunle, G.; Steffen, T. European Green Mutual Fund Performance: A Comparative Analysis with Their Conventional and Black Peers. J. Bus. Ethics 2017, 145, 337-355. [CrossRef]

54. Benson, K.L.; Humphrey, J. Socially Responsible Investment Funds: Investor Reaction to Current and Past Returns. J. Bank. Financ. 2008, 32, 1850-1859. [CrossRef]

55. Renneboog, L.; Horst, J.; Zhang, C. Is Ethical Money Financially Smart? Nonfinancial Attributes and Money Flows of Socially Responsible Investment Funds. J. Financ. Int. 2011, 20, 562-588. [CrossRef]

56. Bollen, N.P.B. Mutual Fund Attributes and Investor Behavior. J. Financ. Quant. Anal. 2007, 42, 683-708. [CrossRef]

57. Bos, J. Sustainability Scores for Investment Funds. CFA Inst. Mag. 2017, 28, 26-28. [CrossRef]

58. Morningstar. The Morningstar Sustainable Investing Handbook. Available online: http://corporate1. morningstar.com/Morningstar-Sustainable-Investing-Handbook.pdf (accessed on 8 August 2017).

59. Morningstar. The Morningstar Sustainability Rating. Available online: http://corporate1.morningstar.com/ Morningstar-Sustainable-Rating-Methodology.pdf (accessed on 8 August 2017).

60. Koenker, R.; Basset, G. Regression Quantiles. Econometrica 1978, 46, 33-50. [CrossRef]

61. Efron, B. Bootstrap Methods: Another Look at the Jackknife. Ann. Stat. 1979, 7, 1-26. [CrossRef] 